\title{
Ruthenium Catalyst Supported on Multi-Walled Carbon Nanotubes for CO Oxidation
}

\author{
Camila Emilia Kozonoe', Reinaldo Giudici1, Martin Schmal1,2* \\ ${ }^{1}$ Department of Chemical Engineering, Escola Politécnica, Universidade de São Paulo, São Paulo, Brazil \\ ${ }^{2}$ Federal University of Rio de Janeiro, COPPE/PEQ/Nucat, Rio de Janeiro, Brazil \\ Email: *schmal@peq.coppe.ufrj.br, *schmal@pqi.eq.usp.br
}

How to cite this paper: Kozonoe, C.E. Giudici, R. and Schmal, M. (2021) Ruthenium Catalyst Supported on Multi-Walled Carbon Nanotubes for CO Oxidation. Modern Research in Catalysis, 10, 73-91. https://doi.org/10.4236/mrc.2021.103005

Received: June 17, 2021

Accepted: July 23, 2021

Published: July 26, 2021

Copyright ( 2021 by author(s) and Scientific Research Publishing Inc. This work is licensed under the Creative Commons Attribution International License (CC BY 4.0).

http://creativecommons.org/licenses/by/4.0/ (c) (i) Open Access

\begin{abstract}
This work proposes the synthesis of the $5 \% \mathrm{wt} \mathrm{Ru}$ on MWCNT catalyst and the influence of feed rate and testing variables for low-temperature oxidation affecting the $\mathrm{CO}_{2}$ yield. Morphology and incorporation of the nanoparticles in carbon nanotubes were investigated by specific surface area (BET method); thermogravimetric analyses (TGA); X-ray diffraction; Raman spectroscopy, transmission electron microscopy (TEM) and XPS. The conversions of CO and $\mathrm{O}_{2}$ were mostly $100 \%$ in groups $\mathrm{C} 1$ and $\mathrm{C} 2$ (temperature between 200 and $500^{\circ} \mathrm{C}$ with low WHSV). In order to assess the effect of mass on catalytic activity, condition $\mathrm{C} 3$ was tested at even lower temperatures. In the tested catalyst, high activity (100\% $\mathrm{CO}$ and $\mathrm{O}_{2}$ conversion) was observed, keeping it active under reaction conditions, suggesting oxi-reduction of the $\mathrm{RuO}_{2}$ at surface without affecting the MWCNT but Lewis acid influencing the $\mathrm{CO}_{2}$ yield.
\end{abstract}

\section{Keywords}

Multi-Walled Carbon Nanotubes, Ruthenium, CO Oxidation

\section{Introduction}

Gaseous pollutants are released into the atmosphere, such as carbon monoxide (CO), causing great damage to the environment, and are known to stay in the Earth's atmosphere for a long time [1].

There are several studies concerning the $\mathrm{CO}$ oxidation of different metals and supports, as reported in the review by Lui and Corma [2]. In fact, the catalytic oxidation of $\mathrm{CO}$ is the most effective process, as reported in the literature [3] [4] [5] [6] [7], using predominantly alumina-support and noble metals ( $\mathrm{Pt}, \mathrm{Ru}, \mathrm{Rh}$, and Pd) [8]-[13] and zeolite-supported platinum [13] [14] [15]. The met- 
al-support interface on oxides and mixed oxides has also demonstrated great effect on the $\mathrm{CO}$ oxidation. Mixed oxide cobalt ferrite $\left(\mathrm{CoFe}_{2} \mathrm{O}_{4}\right)$ nanoparticles exhibited also high CO conversion and good stability [16]. Liu et al. [17] studied the $\mathrm{CO}$ oxidation of the $\mathrm{Pd}$ doping in $\mathrm{Ce}-\mathrm{Zr}$ oxides as one of the most efficient.

However, among the noble metal catalysts, ruthenium has had an unusual catalytic behavior for $\mathrm{CO}$ oxidation [18]-[27]. The Ru single crystal was less active among noble metals under ultrahigh vacuum conditions [18], but highly active under oxidizing and high-pressure conditions [19]. Studies of supported Ru NP catalysts for this reaction have only been sporadically reported [24] [25] [26] [27]. Joo et al. [28] studied the influence of crystal sizes of ruthenium nanoparticles supported on alumina for the CO oxidation activity, which increased with increasing particle sizes. In addition, Soliman [29] studied optimal conditions of the $\mathrm{CO}$ oxidation and the influence of the reaction conditions on the nanostructure of the catalyst.

In fact, oxide supports are not inert materials due to the presence of hydroxyls and large pore sizes. Unlike, the carbon nanotubes (CNT) are inert materials and have been proposed as supports for different reactions, due to the high surface area, allowing the insertion or deposition of the nano-metals or nano metal-oxides, favoring the dispersion and the accessibility of the molecules on the metallic particles. Basically, the nanotube structures have covalent $\mathrm{C}-\mathrm{C}$ bonds formed by layers of graphite. These carbon nanostructures have also uniform pore size distribution, and are resistant at high temperatures. Multi-walled nanotubes (MWCNT) have been used for greatly minimizing the limitations imposed by mass transfer.

However, the synthesized carbon nanotubes need pretreatment for anchoring metallic sites, promoting higher dispersion of the metallic particles [30]. Zeng et al. [31] found that the hydrophilic functional groups of hydroxyl and carboxyl are favorable for the insertion of the metal oxide into the tubes of the MWCNTs. Kozonoe et al. [32] synthesized recently the Ni@MWCNT/Ce catalyst and evaluated the influence of testing variables on reaction performance and nanostructure of the catalyst.

The objective of this work is to synthesize ruthenium oxide NP on multi-walled carbon nanotubes (Nanocyl), the distribution and sizes of nano particles, as well as the nature of both materials on the external walls and the influence of reaction conditions for the $\mathrm{CO}$ oxidation on the activity and $\mathrm{CO}_{2}$ yield, the effect of the reaction on the MWCNT and Ru NP structure and size and surface mechanism.

\section{Materials and Methods}

\subsection{Synthesis of Ruthenium Nanoparticles Supported on Carbon Nanotubes}

Initially, $0.11 \mathrm{~g}$ of Ruthenium (Ruthenium (III) chloride hydrate) was prepared. $3 \mathrm{ml}$ of water was added by dripping to $1 \mathrm{~g}$ of multi-walled carbon nanotubes 
(purchased as Nanocyl-3100). Then, $1.32 \mathrm{ml}$ of ethylene glycol was added to the carbon nanotube and soaked. Finally, the ruthenium solution in ethylene glycol solution was added, and the paste formed was dried under vacuum during three days. The calcination was performed under airflow at $100 \mathrm{ml} \cdot \mathrm{min}^{-1}$, raising the temperature from $30^{\circ} \mathrm{C}$ to $350^{\circ} \mathrm{C}$ at $10^{\circ} \mathrm{C} / \mathrm{min}$, and held for 2 hours. The reduction was performed with hydrogen flow at $100 \mathrm{ml} \cdot \mathrm{min}^{-1}$ from $30^{\circ} \mathrm{C}$ to $400^{\circ} \mathrm{C}$, at $10^{\circ} \mathrm{C} / \mathrm{min}$, and kept for $2 \mathrm{~h}$. The catalyst was denoted as $5 \% \mathrm{Ru} / \mathrm{MWCNT}$.

We also prepared and functionalized CNT sample that was impregnated with the same metallic precursors, according to the procedure reported previously [32].

\subsection{Catalyst Characterization}

The specific surface area of the catalyst was determined using nitrogen physisorption at $-196^{\circ} \mathrm{C}$ in the NOVA 1200 equipment (Surface Area \& Pore Size Analyzer) of Quantachrome Instruments. Prior to the physisorption analysis, the materials were pretreated under vacuum at $200^{\circ} \mathrm{C}$ for $17 \mathrm{~h}$. The specific surface area was determined using the BET methodology.

Transmission Electronic Microscopy (TEM) analyses were performed in a JEOL JEM 2100 Microscope, with maximum acceleration voltage $200 \mathrm{kV}$, and resolution of $0.23 \mathrm{~nm}$ at the point and $0.14 \mathrm{~nm}$ on the network, with maximum magnification of $1,500,000$ times.

$\mathrm{X}$-ray diffraction (XRD) analyses were performed in a Rigaku equipment with an acquisition in the radiation incidence angle range of $2^{\circ}<2 \theta<90^{\circ}$. Identification phases in the sample were obtained using the PDF (Powder Diffraction File PDF2-2003) datasheets as database through the Search-Match program, comparing to their positions in the experimental data.

The Raman spectra were acquired in the range of $100-3500 \mathrm{~cm}^{-1}$ with a Renishaw in Via confocal Raman microscope in backscattering geometry equipped with a CCD detector $\left(-70^{\circ} \mathrm{C}\right)$ and HeNe laser supplying the photon at $532 \mathrm{~nm}$. The laser excitation power was kept below $10 \mathrm{~mW}$ on the sample surface to minimize the local heating. The total acquisition time was 300s. All the spectra of the samples after reaction were recorded under identical conditions at room temperature.

The surface of the catalysts was studied using X-ray photoelectron spectroscopy (XPS). X-ray photoelectron spectra were recorded on a Leybold-Heraeus LHS 10 spectrometer using a non-monochromatized Al-K- $\alpha$ source $(1486.7 \mathrm{eV})$.

Thermal analyses of the samples before and after reaction were performed on a DTG-60H Shimadzu with a TG-DTG simultaneous analyses accessory. The measurements were conducted under a flow of nitrogen/oxygen mixture (55 $\mathrm{mL} / \mathrm{min} \mathrm{N}_{2} / 8 \mathrm{~mL} / \mathrm{min}_{2}$ ) from 25 to $1000^{\circ} \mathrm{C}$ at a heating rate of $10^{\circ} \mathrm{C} / \mathrm{min}$.

\subsection{Activity Tests}

The tests were performed in a Microactivity-Effi (PID company) with a Hastel- 

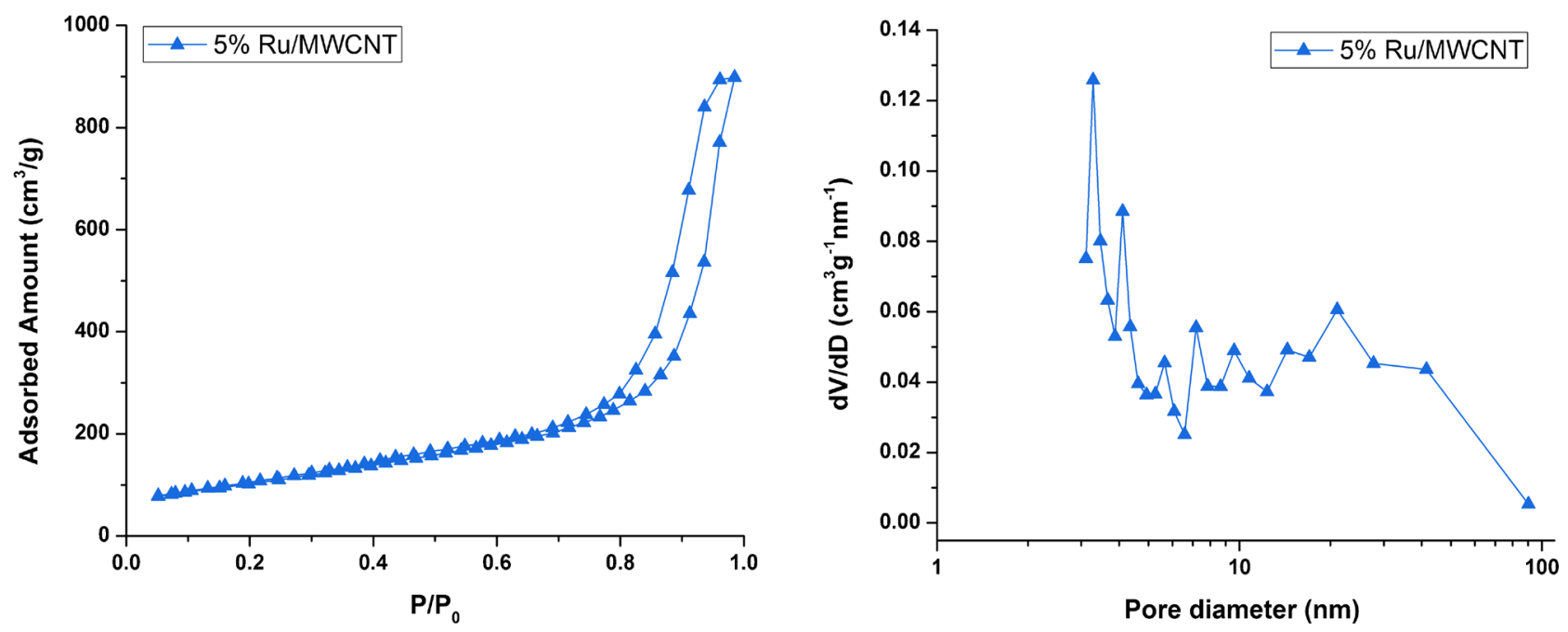

Figure 1. Nitrogen adsorption-desorption isotherms, the corresponding pore size distribution of the Ru/MWCNT catalyst. 
Noteworthy is that the depositions of Ru particles (Figures A and B) are well dispersed on the external wall of the CNT.

In fact, transmission electron microscopic analyses generate two-dimensional images, allowing determining the location of the particles in some selected regions.

We calculated the average diameter of the nanotubes and particles from the images using the ImageJ software and obtained the particle size distribution from a representative group of 12 images.

The average diameter for the Ru located at the external wall of the carbon nanotubes was $2.3 \pm 0.6 \mathrm{~nm}$, very close to the calculated by the X-ray diffraction, XRD $(1.7 \mathrm{~nm})$.

Figure 3 displays the average external and internal diameter of the carbon nanotubes, $13.4 \pm 2.7$ and $6.8 \pm 1.6 \mathrm{~nm}$, respectively. The sample space presents 32 tubes.

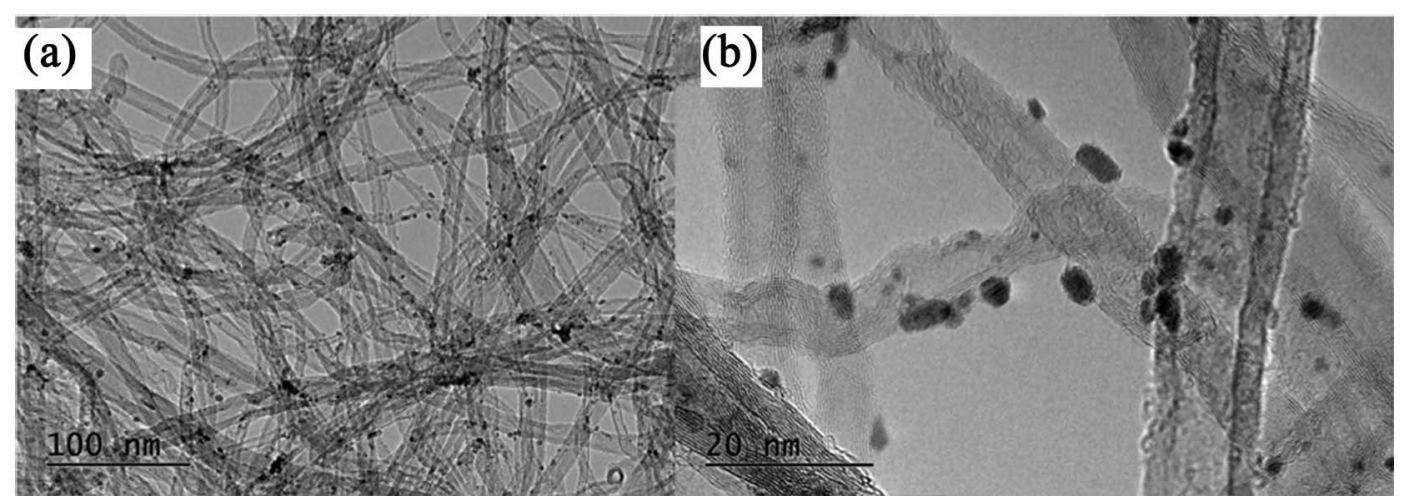

Figure 2. Images of transmission electron microscopy (TEM) of the carbon nanotubes decorated with $\mathrm{Ru}$ (5\%Ru/MWCNT) ((a), (b)).

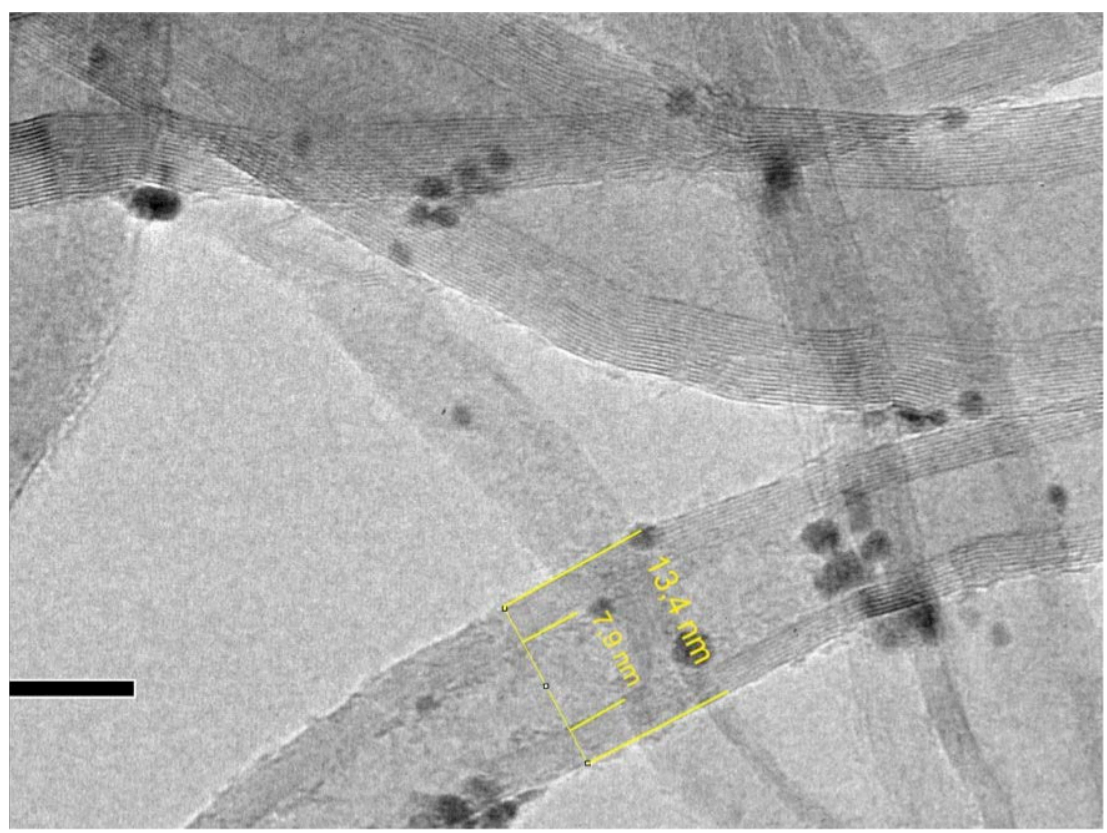

Figure 3. The capture of a carbon nanotube with external impregnation with $50 \mathrm{~nm}$ resolution. 


\subsection{X-Ray Analyses (XRD)}

Figure 4 shows the X-ray diffractograms for the MWCNT and of the catalyst. According to the literature [33], the MWCNT present characteristic peaks at $2 \theta$ $\approx 26.2^{\circ}, 43.0^{\circ}, 55.0^{\circ}$, and $77.0^{\circ}$, which represent, respectively, the (002), (100), (004) and (110) planes. The first peak indicates the presence of the effect of different overlapping graphene sheets, in a concentric mode [34], characteristic of multi-layered carbon nanotubes.

The profile obtained for MWCNT (Figure 4) showed the peaks of the planes (002) and (100) at $2 \theta$ equal to $26.05^{\circ}$ and $43.03^{\circ}$, respectively. In addition, such peaks are broad, characteristic of amorphous materials, as expected for carbon nanotubes.

The diffractogram of the catalyst with ruthenium showed the presence of two peaks with low intensity at $34.8^{\circ}$ and $54.8^{\circ}$, which are assigned to $\mathrm{RuO}_{2}$ (Ref. code 40-1290 and overlap identified by "*” in Figure 5) present at the external surface of the MWCNT, in agreement with the images of electron transmission microscopy analyses. For comparison, the XRD of the functionalized MWCNTf diffractogram is presented in supplementary information S1.

The crystallite size of ruthenium was calculated using Scherrer's equation [35]. For this, the peak of $34.8^{\circ}$ was used, which resulted in a crystallite size of $1.7 \mathrm{~nm}$ in agreement with TEM result of $2.3 \pm 0.6 \mathrm{~nm}$. Rojas et al. [36] found metallic Ru particles of $2.5 \mathrm{~nm}$ on the Ru/MWCNT sample.

\subsection{Thermogravimetric Analyses (TGA)}

The thermogravimetric analyses (TGA) and their derivate (DTG) profiles of the Ru/MWCNT catalysts are shown in Figure 6, presenting the weight loss of the pure carbon nanotube (MWCNT) and of the catalyst (Ru/MWCNT).

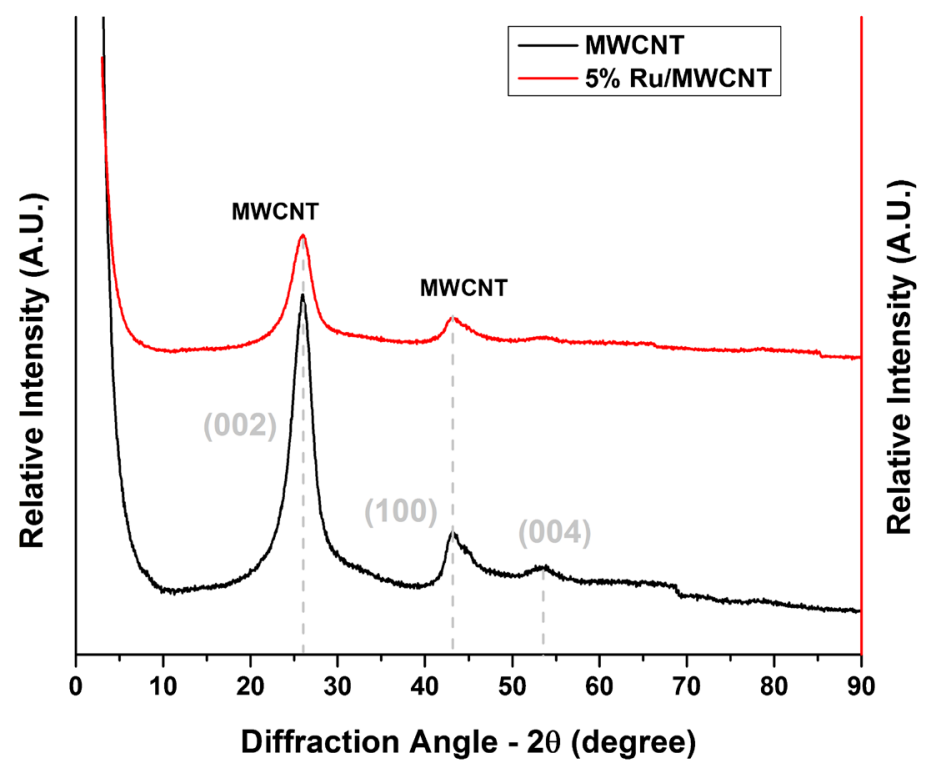

Figure 4. XRD of the carbon nanotubes (MWCNT) and the carbon nanotubes $5 \%$ $\mathrm{Ru} / \mathrm{MWCNT}$ catalyst. 


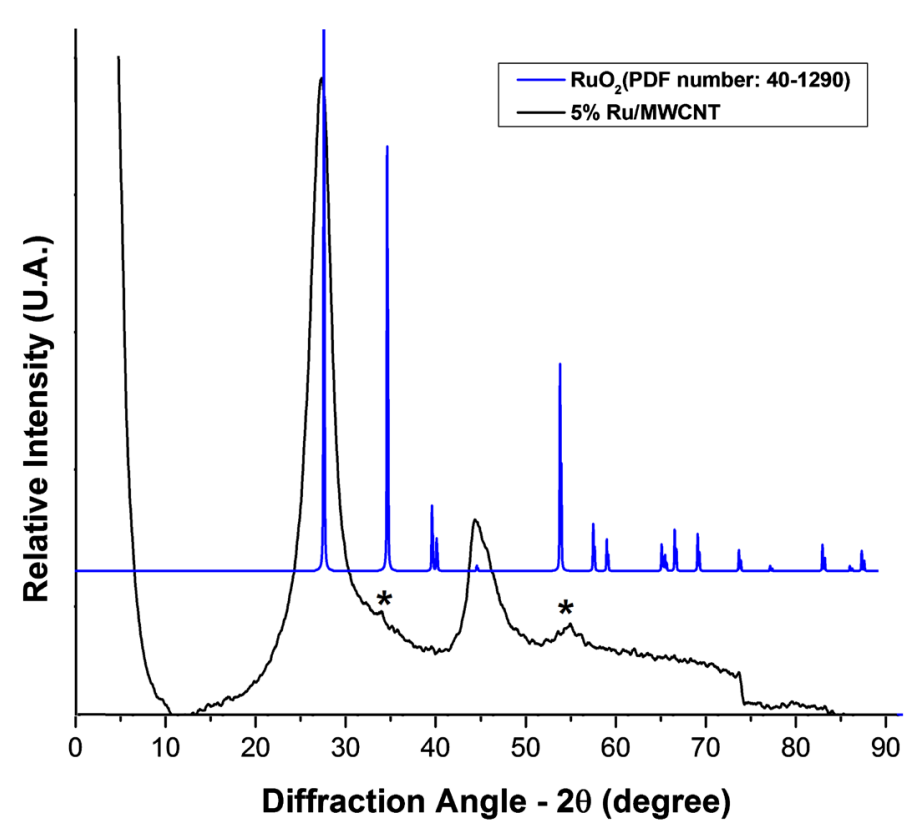

Figure 5. Diffractogram for the carbon nanotube impregnated with ruthenium externally.
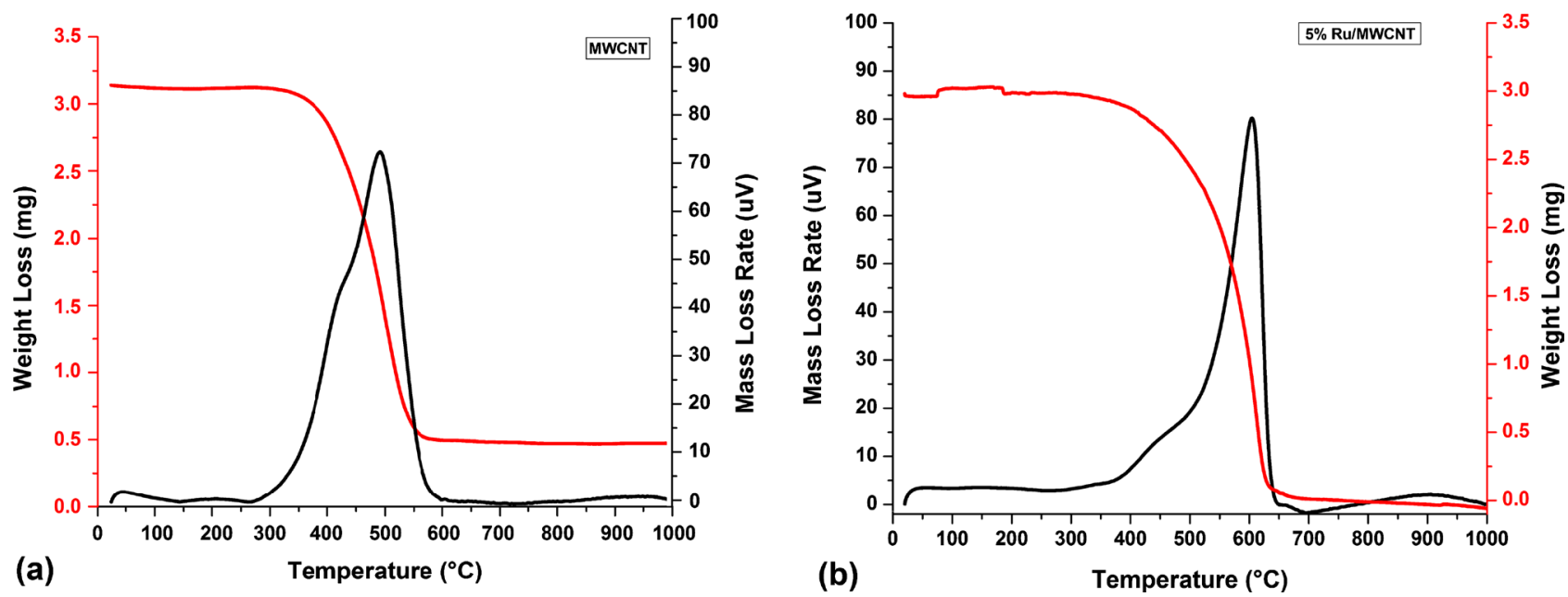

Figure 6. TGA and DTA curve of the MWCNT sample (a) and 5\% Ru/MWCNT catalyst (b).

The TGA analysis (red curve) shows that the support (MWCNT) and the catalyst (5\% Ru/MWCNT) present slightly different profiles. For the support, the mass loss was approximately $84 \%$ at $515^{\circ} \mathrm{C}$, and for the catalyst, was $92 \%$ at approximately $600^{\circ} \mathrm{C}$, which indicates decomposition of the carbonyl and carboxylic groups present in carbon nanotubes, in accordance with Saleh et al. [37].

\subsection{Raman Spectroscopy}

Raman spectroscopic analyses provide information about the chemical composition and crystalline structure of the sample [38]. Figure 7 shows the spectra of the carbon nanotube and the catalyst. The spectrum of the MWCNT showed the peaks at bands $\mathrm{D}\left(\approx 1340 \mathrm{~cm}^{-1}\right), \mathrm{G}\left(\approx 1572 \mathrm{~cm}^{-1}\right), 2 \mathrm{D}\left(\approx 2663 \mathrm{~cm}^{-1}\right), \mathrm{G}+\mathrm{D}(\approx 2919$ $\left.\mathrm{cm}^{-1}\right)$, in accordance with Zdrojek et al. [39] and noise bands between 100 and 


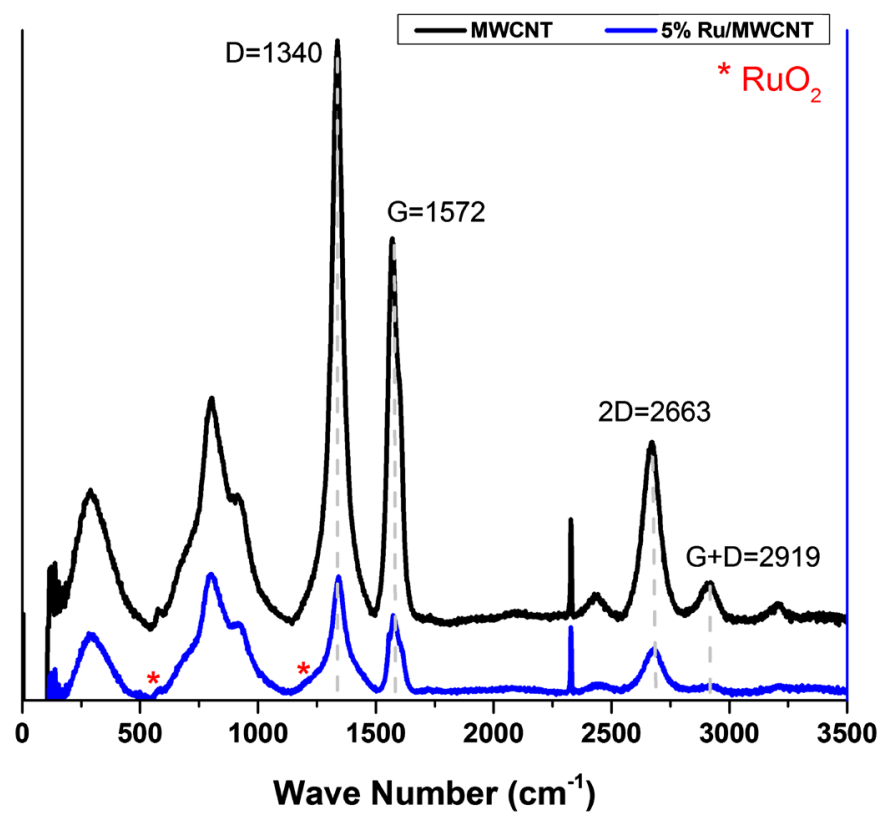

Figure 7. Raman spectra take from pure carbon nanotubes and the MWCNT covered with $\mathrm{Ru}(5 \% \mathrm{Ru} / \mathrm{MWCNT})$ at $\lambda=532 \mathrm{~nm}$.

$200 \mathrm{~cm}^{-1}$, as observed by Ivanova et al. [40]. However, the spectrum of the catalyst sample showed extra peaks, which could be correlated to impurities $(\approx 2330$ $\mathrm{cm}^{-1}, 800 \mathrm{~cm}^{-1}$ and $\left.270 \mathrm{~cm}^{-1}\right)$.

The band $\mathrm{G}$ (graphite) corresponds to the vibrations of the $\mathrm{sp}^{2}$ bonds between the carbons in the same plane and the band $\mathrm{D}$ to the disorder in the carbon structure, that is, the $\mathrm{sp}^{3}$ bonds between the carbons. The ratio between the areas of these peaks $\left(\mathrm{I}_{\mathrm{D}} / \mathrm{I}_{\mathrm{G}}\right)$ allows determining the quality of carbon nanotubes [41], representing the density of structural defects. The higher the ratio, the more defects ( $\mathrm{sp}^{3}$ connections) are present in relation to the expected ( $\mathrm{sp}^{2}$ connections). The ratio of the pure support was 1.98 .

This ratio increased after the addition of ruthenium (2.80). In fact, it indicates that there is an exchange of double bond for single bond in the carbons, with the formation of new covalent bonds. Figure 7 shows the peaks in the region at lower wavenumbers, indicating the presence of the metal oxide, probably ruthenium oxide, $\mathrm{RuO}_{2}$ (set of 2 small peaks, between 510 and $1300 \mathrm{~cm}^{-1}$ ) as indicated in the figure and in accordance with the literature [42]. In fact, $\mathrm{RuO}_{2}$ is probably the main oxide present at the external surface of the MWCNT. Literature reported different oxidation states of the $\mathrm{Ru}$, but in particular the $\mathrm{Ru}^{+4}$ and $\mathrm{Ru}^{+8}$, besides other oxidation states that were reported in literature. For comparison, the Raman spectrum of the functionalized MWCNTf is also presented in supplementary information $\mathrm{S} 1$.

\subsection{X-Ray Spectroscopy (XPS) of Ru/MWCNT}

The XPS analyses were performed for identifying the oxidation state of ruthenium oxide deposited on the outer surface of the CNT, and also identifying the 
functional groups of the MWCNT. All binding energies were corrected, referencing the $\mathrm{C} 1 s(284.6 \mathrm{eV})$ peak of the contamination carbon as an internal standard. The XPS experiments were obtained for the functionalized MWCNT with the same content of $5 \% \mathrm{Ru}$. The XPS results are important to explain the presence of the $\mathrm{RuO}_{2}$ at the surface, not well seen in the XRD and Raman spectra. In fact, Figure 8(a) shows the screening spectrum of carbon, ruthenium and have oxygen.

Figure 8(b) shows the deconvolution of C1s peak. Results showed graphitic carbon at $284.3 \mathrm{eV}$ [41]. Peaks at 284.5 and $290.5 \mathrm{eV}$ are assigned to the carbon atoms $(\mathrm{C}-\mathrm{C})$ attached to groups containing oxygen $(\mathrm{C}=\mathrm{O})$ in their structure [43]. The electronic transition of orbitals $\pi \rightarrow \pi^{*}$ was associated with the peak at $290.5 \mathrm{eV}$. These results indicate the external surface and also that the graphite layers retained their original structure [28] [31].

The spectrum the $\mathrm{Ru} 3 \mathrm{~d}$ is characterized by a pair corresponding to the $5 / 2$ and 3/2 spin-orbit components located at 281.4 and $285.6 \mathrm{eV}$, respectively (not
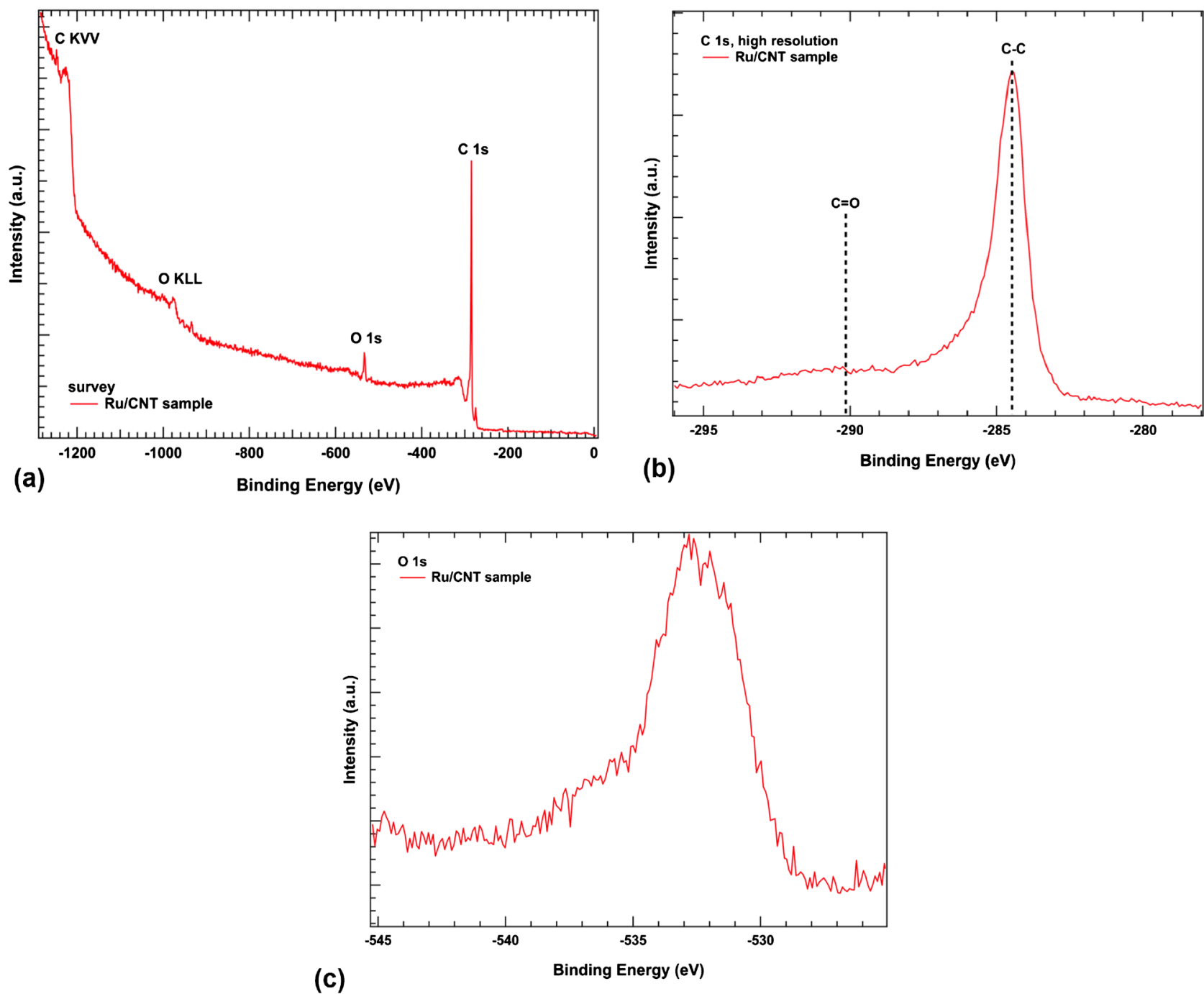

Figure 8. XPS spectra of the Ru/MWCNTt (a) screening, (b) Carbon C and (c) Oxygen $\mathrm{O}_{1 s}$. 
shown). Figure $8(\mathrm{c})$ displays the $\mathrm{O}$ 1s core level spectrum of the $\mathrm{RuO}_{2}$ on distinct maxima located at $530.1 \mathrm{eV}$, associated with oxygen adsorbed on the surface and 532.0, 532.8 and $534.0 \mathrm{eV}$, assigned carboxylic and hydroxyl groups. These peaks were related to the metallic oxides on the external surface of the CNTs.

\subsection{Catalytic Activity}

The catalyst ( $5 \% \mathrm{Ru} / \mathrm{MWCNT}$ ) was tested in the $\mathrm{CO}$ oxidation reaction, for different conditions (3 groups), as presented in Table 1, to show the influence of temperature and space velocity. The conversion and selectivity results are presented in this table and illustrated in Figure 9. Each experiment was carried out in triplicate with the same sample and conditions, and constant mass.

Tests for condition C3 were obtained at WHSV 13,285 (mL/min.g) and mass of $20 \mathrm{mg}$, consequently, low contact time. The $\mathrm{CO}$ and $\mathrm{O}_{2}$ conversions with temperatures between 50 and $270^{\circ} \mathrm{C}$ are displayed in Figure 9. In fact, the conversions of $\mathrm{CO}$ and $\mathrm{O}_{2}$ increased, from $50^{\circ} \mathrm{C}$, reaching the maximum conversions of $75 \%$ and $100 \%$, respectively, at $150^{\circ} \mathrm{C}$, but the selectivity of $\mathrm{CO}_{2}$ was around $85 \%$.

The results for condition C1, for lower space velocity (WHSV) 2000 (mL/min.g)

Table 1. Conversion and selectivity results for different experimental conditions of the $\mathrm{CO}$ oxidation using $5 \% \mathrm{Ru} / \mathrm{MWCNT}$ catalyst.

\begin{tabular}{|c|c|c|c|c|c|c|c|}
\hline Group & $\mathrm{T}\left({ }^{\circ} \mathrm{C}\right)$ & Mass (g) & $\begin{array}{c}\text { WHSV } \\
(\mathrm{mL} / \mathrm{min} \cdot \mathrm{g})\end{array}$ & $\begin{array}{c}\left(\mathrm{CO}: \mathrm{O}_{2}: \mathrm{N}_{2}\right) \\
(\mathrm{ml} / \mathrm{min})\end{array}$ & $\mathrm{X}_{\mathrm{CO}}(\%)$ & $\mathrm{X}_{\mathrm{O} 2}(\%)$ & $\mathrm{S}_{\mathrm{CO} 2}(\%)$ \\
\hline $\mathrm{C} 11$ & 300 & & & & 100 & 95.2 & 107.1 \\
\hline $\mathrm{C} 12$ & 350 & & & & 100 & 95.5 & 107.6 \\
\hline $\mathrm{C} 13$ & 400 & 0.1 & 2000 & $(1: 0.5: 1.32)$ & 100 & 95.4 & 108.2 \\
\hline $\mathrm{C} 14$ & 450 & & & & 100 & 95.4 & 108.1 \\
\hline $\mathrm{C} 15$ & 500 & & & & 100 & 95.5 & 108.0 \\
\hline $\mathrm{C} 21$ & 200 & & & & 100 & 100 & 88.9 \\
\hline $\mathrm{C} 22$ & 250 & & & & 100 & 100 & 88.7 \\
\hline $\mathrm{C} 23$ & 300 & 0.1 & 2657 & $(1: 0.47: 5.91)$ & 100 & 100 & 88.5 \\
\hline $\mathrm{C} 24$ & 350 & & & & 100 & 100 & 88.6 \\
\hline $\mathrm{C} 25$ & 400 & & & & 100 & 100 & 88.8 \\
\hline C31 & 50 & & & & 10.3 & 23.5 & 28.0 \\
\hline C32 & 75 & & & & 11.7 & 27.2 & 45.6 \\
\hline C33 & 120 & & & & 55.0 & 80.7 & 82.5 \\
\hline C34 & 150 & 0.02 & 13285 & $(1: 0.34: 5.35)$ & 74.8 & 100 & 84.7 \\
\hline C35 & 190 & & & & 75.1 & 100 & 85.2 \\
\hline C36 & 210 & & & & 74.9 & 100 & 85.8 \\
\hline C37 & 270 & & & & 75.4 & 100 & 88.0 \\
\hline
\end{tabular}



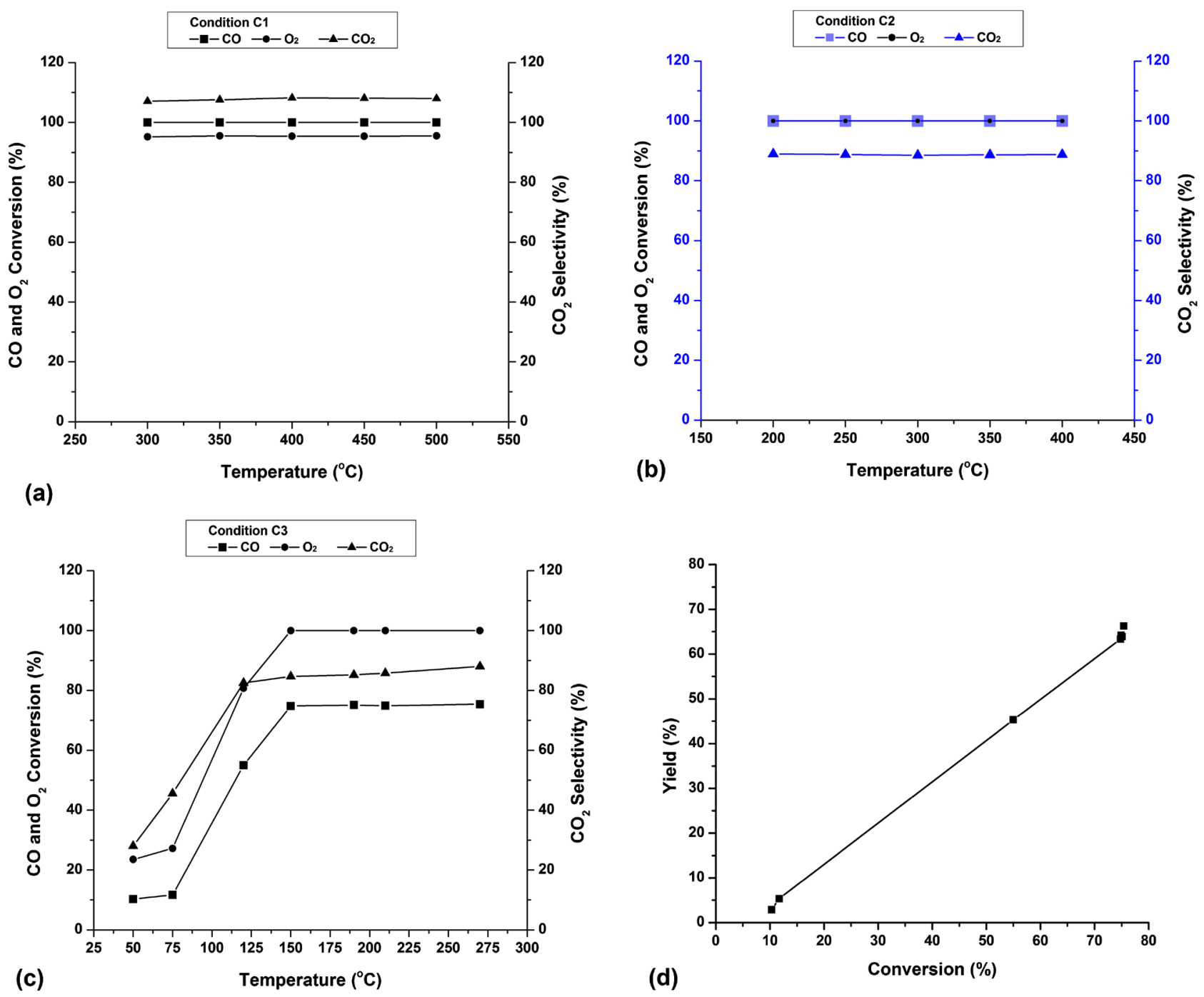

Figure 9. Conversions of $\mathrm{CO}$ and $\mathrm{O}_{2}$, selectivity and yield of $\mathrm{CO}_{2}$ for the $5 \% \mathrm{Ru} / \mathrm{MWCNT}$ catalyst in the evaluation of the effects of the space velocity and temperature.

and CO: $\mathrm{O}_{2}=1: 0.5$, and temperatures between $300^{\circ} \mathrm{C}$ and $500^{\circ} \mathrm{C}$, showed conversions of carbon monoxide $100 \%$, and of $\mathrm{O}_{2}$ around $95 \%$. However, the $\mathrm{CO}_{2}$ yield was higher than $100 \%$.

Conditions $\mathrm{C} 2$ were tested, diluting the reagents at the feed entrance (CO: $\left.\mathrm{O}_{2}: \mathrm{N}_{2}=1: 0.47: 5.91\right)$, by increasing the volume of the inert gas $\mathrm{N}_{2}$ and the space velocity of $2657 \mathrm{~mL} / \mathrm{min} . \mathrm{g}$, and increasing the temperature from $200^{\circ} \mathrm{C}$ to $400^{\circ} \mathrm{C}$. The carbon monoxide and $\mathrm{O}_{2}$ reached maximum conversions of $100 \%$, suggesting total oxidation of $\mathrm{CO}$; however, the $\mathrm{CO}_{2}$ selectivity was $88 \%$.

We calculated the yield, using equation: $\mathrm{Y}(\mathrm{j})=\mathrm{X}(\mathrm{CO}) \times \mathrm{S}(\mathrm{j})$, and results are shown in Figure 9(d), with increasing conversion. As shown yield increased linearly with the conversion.

\section{Discussion}

In fact, these results may indicate the concomitant occurrence of reactions. In 
experiments $\mathrm{C} 1$ occurred the Bourdouard reaction with the formation of Carbon and $\mathrm{CO}_{2}$, besides the partial oxidation of $\mathrm{C}$ formed at higher temperature. Under this temperature range without combustion of the CNT, as evidenced in the TGA and DTG results in Figure 6 or partial decomposition of the carbon support:

$$
\begin{gathered}
2 \mathrm{CO} \rightarrow \mathrm{C}+\mathrm{CO}_{2} \\
\mathrm{C}+\mathrm{O}_{2} \rightarrow \mathrm{CO}_{2}
\end{gathered}
$$

Noteworthy are the experiments $\mathrm{C} 3$, showing that between $50^{\circ} \mathrm{C}$ and $150^{\circ} \mathrm{C}$ at a space velocity $13,285 \mathrm{~mL} / \mathrm{min}$.g, the conversion of $\mathrm{O}_{2}$ is higher than of $\mathrm{CO}$ with simultaneous $\mathrm{CO}_{2}$ formation, indicating that besides the $\mathrm{CO}$ oxidation it consumes more oxygen for the oxidation of $\mathrm{RuO}_{2}$ to higher oxidation state. However, between $150^{\circ} \mathrm{C}$ and $270^{\circ} \mathrm{C}$, the oxygen conversion is $100 \%$ while the $\mathrm{CO}_{2}$ selectivity is lower, varying from $84 \%$ to $88 \%$, besides higher conversion of $\mathrm{CO}$, reaching $75 \%$, which suggests the reduction of $\mathrm{RuO}_{2}$ to metallic $\mathrm{Ru}^{0}$, with simultaneous formation of carbonate as shown below. So, there is a simultaneous reduction and oxidation process during the reaction, noted on experiments $\mathrm{C} 1$ and C2. For higher temperatures, the CNT is partially decomposed or oxidized.

In fact, these experiments suggest that $\mathrm{CO}$ probably reduces the $\mathrm{RuO}_{2}$ in the metallic Ru or form carbonate according to the literature [44]:

$$
\begin{gathered}
\mathrm{RuO}_{2}+\mathrm{CO} \rightarrow \mathrm{Ru}^{0}+\mathrm{CO}_{3}^{-} \\
\mathrm{RuO}_{2}+\mathrm{CO} \rightarrow \mathrm{Ru}_{2} \mathrm{CO}_{3}^{-} \rightarrow \mathrm{C}_{3} \mathrm{O}_{9} \mathrm{Ru}_{2}
\end{gathered}
$$

In conclusion, these results evidenced high performance like the reducible oxide supports and depend mainly on the distribution of particle sizes, but not on their sizes. The selectivity of $\mathrm{CO}_{2}$ depends on the temperature range and on the oxidative-reductive cycle of the metal oxide-metal. For the MWCNT support we found particle sizes of $\mathrm{Ru}$ oxide around $2.3 \mathrm{~nm}$, which resulted in very high $\mathrm{CO}$ and $\mathrm{O}_{2}$ conversions, but influencing also the $\mathrm{CO}_{2}$ selectivity.

Liu et al. [4] studied the $\mathrm{CO}$ oxidation on $\mathrm{Pd}-\mathrm{Ce}_{0.8} \mathrm{Zr}_{0.2} \mathrm{O}_{2}$ (mixed oxide) with $\mathrm{Pd}$ that presented the high activity and complete $\mathrm{CO}$ conversion at $110^{\circ} \mathrm{C}$. Due to the metal-support interface interaction with oxide support, they claimed that the introduction of Pd promoted the formation of oxygen vacancy. Authors suggested that the $\mathrm{CO}$ molecule directly reacts with a surface $\mathrm{O}$ atom neighboring the Pd dopant, leading to the formation of $\mathrm{CO}_{2}$ and a surface $\mathrm{O}$ vacancy, without any activation energy. Ananth et al. [43] studied the $\mathrm{CO}$ oxidation on $\mathrm{RuO}_{2} / \mathrm{Al}_{2} \mathrm{O}_{3}$ catalyst, and showed complete $\mathrm{CO}$ oxidation at $200^{\circ} \mathrm{C}, 225^{\circ} \mathrm{C}$, and $300^{\circ} \mathrm{C}$, similar to these results obtained for the same temperature range and at space velocity between 2000 and 2657 (mL/min.g). Therefore, it can be attributed to the high distribution and dispersion of metal oxide over an MWCNT, due to the high surface area, which influences the $\mathrm{CO}_{2}$ selectivity. In fact, condition C3 showed for $74.8 \%$ CO conversion and 100\% oxygen conversion at $150^{\circ} \mathrm{C}$, and $84.5 \% \mathrm{CO}_{2}$ selectivity (Table 1 ).

The $\mathrm{CO}$ oxidation activity depends on the surface property, high surface areas, 
and mesoporous structure of the catalyst. Park et al. [45] observed that the $\mathrm{H}_{2}$ pretreatment of meso- $\mathrm{RuO}_{2}$ results in the collapse of the mesostructure and a change $\mathrm{RuO}_{2}$ phase, as discussed above, which corroborates our results. The catalytic activity at low temperature is high for Ru/MWCNT, which may also be attributed to the high distribution of $\mathrm{RuO}_{2}$-based catalysts anchored on the MWCNT due to the high surface area $285 \mathrm{~m}^{2} / \mathrm{g}$.

According to Joo et al. [28] the size of $\mathrm{Ru}$ nanoparticles affects the $\mathrm{CO}$ oxidation, and with increasing particle size the activity. The particle sizes of this work are of the order of $2.3 \mathrm{~nm}$ and showed high activity. They observed for $\mathrm{Ru} / \mathrm{SiO}_{2}$ for 3 and $5 \%$ particle sizes between 2 and $6 \mathrm{~nm}$ and energy of activations of 22.2 and $22.5 \mathrm{kcal} / \mathrm{mol}$, suggesting a low barrier, which increases the activity in the presence of Ru NP.

The activity can be determined for the half-time reaction of $\mathrm{CO}$ and oxygen conversion. In Figure 9 we observe the temperature for 50\% conversion of $\mathrm{CO}$ and $\mathrm{O}_{2}$ are $120^{\circ} \mathrm{C}$ and $80^{\circ} \mathrm{C}$, respectively, which compared to Reddy et al. [46], who observed for the copper catalysts supported on alumina the same temperature around $120^{\circ} \mathrm{C}$, for a CO conversion around $60 \%$. The light-off temperature of the Ru catalyst around $110^{\circ} \mathrm{C}-120^{\circ} \mathrm{C}$ is also in good agreement with the $\mathrm{Ru}$ on $\mathrm{Al}_{2} \mathrm{O}_{3}$.

However, there may occur structural changes due to the reaction. Joo et al. [28] showed through in situ spectroscopic analyses the as-prepared metallic Ru nanoparticle transformed into core-shell structure $\left(\mathrm{Ru} @ \mathrm{RuO}_{2}\right)$ under reaction conditions, and the fraction of $\mathrm{RuO}_{2}$ overlayer was related to the particle size. Therefore, the size-dependent redox properties of Ru nanoparticles may account the $\mathrm{CO}$ oxidation.

\subsection{Thermogravimetric Analysis of Spent Catalyst}

The thermogravimetric analysis (TGA) was performed after reaction in air atmosphere (Figure 10). Noteworthy is that the profile shows gain of mass from $250^{\circ} \mathrm{C}$ up to $700^{\circ} \mathrm{C}$, and the DTG profile shows a maximum peak at $320^{\circ} \mathrm{C}$, decreasing then up to $750^{\circ} \mathrm{C}$, and afterwards increases without mass alteration. It evidences an oxidation step of the metallic particles starting at $450^{\circ} \mathrm{C}$ up to $700^{\circ} \mathrm{C}$. According to these results, the mass gain is suggested to be attributed to the carbon formation, and principally to the oxidation of Ru species [11]. These last results may explain the phase transformation without decomposition of the CNT.

The thermogravimetric analysis (TGA and DTA) results indicate between $200^{\circ} \mathrm{C}$ and $400^{\circ} \mathrm{C}$ the reduction besides the oxidation of $\mathrm{RuO}_{2}$ to $\mathrm{RuO}_{4}$ due to the gain of mass, as shown in Figure 9, that is:

$$
\mathrm{RuO}_{2}+\mathrm{O}_{2} \rightarrow \mathrm{RuO}_{4}
$$

In fact, it supports the original hypothesis of spectroscopic analyses that the metallic $\mathrm{Ru}$ nanoparticle are transformed into core-shell structure $\left(\mathrm{Ru} @ \mathrm{RuO}_{2}\right)$ under reaction conditions, according to Joo et al. [28]. 


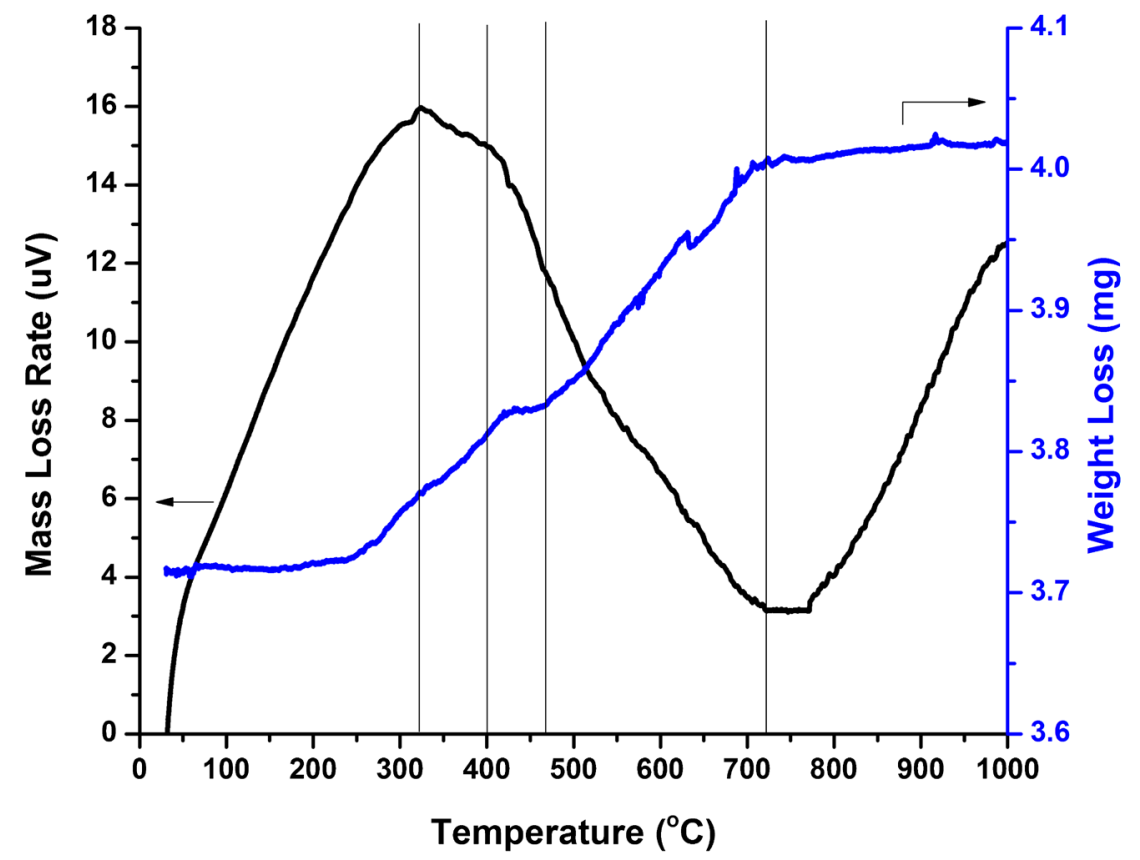

Figure 10. TGA and DTG curves of the Ru/MWCNT catalyst after reaction.

Moreover, Figure 10 shows gain of mass between $450^{\circ} \mathrm{C}$ and $720^{\circ} \mathrm{C}$ and DTA profile evidence transformation of phases attributed mainly the oxidation of $\mathrm{RuO}_{2}$ with a gain of mass to $\mathrm{RuO}_{4}$, in good agreement with TGA and DTA results of the original catalyst in Figure 6(b) and in accordance with the XPS results. The O1s core level spectrum of the $\mathrm{RuO}_{2}$ displays oxygen adsorbed on the surface, which is associated with oxygen from Ruthenium oxides. There are no references reported in the literature concerning this behavior.

\subsection{Reaction Mechanism}

According to the literature [45] authors suggested that the mechanism of $\mathrm{CO}$ oxidation on the $\mathrm{RuO}_{2}$ surface is explained by the adsorption and reaction of atomic oxygen species on the coordinative unsaturated $\mathrm{Ru}$ atoms and bridge position surface oxygen atoms as verified by Mars-van Krevelan.

Therefore, we propose a reaction mechanism that follows the scheme presented below. In the first stage the $\mathrm{RuO}_{2}$ present as nanoparticles can be reduced in the presence of $\mathrm{CO}$ molecule, with the formation of $\mathrm{Ru}^{0}$ metallic. Besides this $\mathrm{RuO}_{2}$ can also be reduced with the formation of a carbonate specie $\left(\mathrm{Ru}_{2} \mathrm{CO}_{3}^{-}\right)$ and in sequence to the formation of Ruthenium carbonate $\left(\mathrm{C}_{3} \mathrm{O}_{9} \mathrm{Ru}_{2}\right)$ that is inert, but can be decomposed. Then the metallic $\mathrm{Ru}^{0}$ is oxidized regenerating the $\mathrm{RuO}_{2}$, which completes the oxi-reduction stage. However, the MWCNT present $\mathrm{OH}^{-}$hydroxyls as evidenced by XPS, which can combine with the carbonate and formation of $\mathrm{CO}_{3}^{-}+\mathrm{OH} \rightarrow \mathrm{HCO}_{3}^{-}+\mathrm{O}^{-}$, releasing $\mathrm{O}^{-}$at the surface of the CNT and react with $\mathrm{CO}$ to form $\mathrm{CO}_{2}$, which was observed in all experiments, indicating higher yields than realeased from the direct oxidation of $\mathrm{CO}$ with oxygen. 
The following scheme represents the mechanism of the $\mathrm{CO}$ oxidation on $\mathrm{RuO}$ supported on MWCNT:

$$
\begin{gathered}
\mathrm{RuO}_{2}+\mathrm{CO} \rightarrow \mathrm{Ru}^{0}+\mathrm{CO}_{3}^{-} \\
\mathrm{RuO}_{2}+\mathrm{CO} \rightarrow \mathrm{Ru}_{2} \mathrm{CO}_{3}^{-} \rightarrow \mathrm{C}_{3} \mathrm{O}_{9} \mathrm{Ru}_{2} \\
\mathrm{RuO}_{2}+\mathrm{O}_{2} \rightarrow \mathrm{RuO}_{4} \\
\mathrm{Ru}^{0}+\mathrm{O}_{2} \rightarrow \mathrm{RuO}_{2} \\
\mathrm{CO}_{3}^{-}+\mathrm{OH} \rightarrow \mathrm{HCO}_{3}^{-}+\mathrm{O}^{-} \\
\mathrm{CO}+\mathrm{O}^{-} \rightarrow \mathrm{CO}_{2}
\end{gathered}
$$

Therefore, this agrees with Park et al. [45], suggesting the mechanism of CO oxidation on the $\mathrm{RuO}_{2}$ surface through the adsorption and reaction of atomic oxygen species $\left(\mathrm{O}^{-}\right)$, as identified by XPS, which can be attributed to the coordinative unsaturated $\mathrm{Ru}$ atoms.

However, for higher temperatures $300^{\circ} \mathrm{C}-400^{\circ} \mathrm{C}$ one observed higher release of $\mathrm{CO}_{2}$, which can be explained by the Bourdourd reaction and carbon oxidation ( $2 \mathrm{CO} \rightarrow \mathrm{C}+\mathrm{CO}_{2} ; \mathrm{C}+\mathrm{O}_{2} \rightarrow \mathrm{CO}_{2}$ ), that were observed by TGA analysis too.

In fact, this support MWCNT does not supply oxygen like the reducible mixed oxides support. But, it can be attributed to the presence of Lewis sites (Equation (7)) with the adsorption of molecular oxygen and release of atomic oxygen for the reaction with $\mathrm{CO}$ (Equation (8)), but depending also on the temperature range can influence the $\mathrm{CO}_{2}$ yield.

\section{Conclusion}

In this work, the ruthenium catalyst added on outside multi-walled carbon nanotubes (MWCNT) was synthesized. The BET surface area results revealed that the catalyst exhibited a high specific surface area of about $285 \mathrm{~m}^{2} / \mathrm{g}$. The TEM studies confirm the presence of $\mathrm{Ru}$ nanoparticles impregnated on the outside of the carbon nanotubes and have excellent distribution. The X-ray diffraction revealed the sub-tile presence of the ruthenium. Thermogravimetric analysis of the synthesized sample indicated that the prepared catalyst is thermally stable up to $500^{\circ} \mathrm{C}$, showing a peak of degradation at $600^{\circ} \mathrm{C}$. The activity for $\mathrm{CO}$ oxidation reaction was studied considering different feed conditions and temperatures. In the tested catalyst, high activity (100\% $\mathrm{CO}$ and $\mathrm{O}_{2}$ conversion) were observed, keeping the catalyst active under reaction conditions, suggesting that the $\mathrm{RuO}_{2}$ surface provides oxygen species to react with $\mathrm{CO}$, thereby regenerating the consumed oxygen atoms. XPS results displayed oxygen adsorbed on the surface, which are associated with oxygen from Ruthenium oxides and Lewis acid sites on the MWCNT with caption of molecular oxygen and formation of atomic oxygen, influencing the activity and $\mathrm{CO}_{2}$ selectivity.

\section{Acknowledgements}

The authors gratefully acknowledge the support of the RCGI, Research Centre 
for Gas Innovation, hosted by the University of São Paulo (USP) and sponsored by FAPESP, São Paulo Research Foundation (2014/50279-4). This study was financed in part by the Coordenação de Aperfeiçoamento de Pessoal de Nível Superior, Brasil (CAPES), Finance Code 001. Many thanks to graduate students in chemical engineering (Giovanna Merces, Fabio Chirumpolo and Clara Ferreira) for their help with catalyst characterization analyzes. We thank collaboration of Technische Universität München (Germany) for XPS measurements.

\section{Conflicts of Interest}

The authors declare no conflicts of interest regarding the publication of this paper.

\section{References}

[1] Weaver, L.K. (1999) Carbon Monoxide Poisoning. Critical Care Clinics, 15, 297-317. https://doi.org/10.1016/S0749-0704(05)70056-7

[2] Liu, L. and Corma, A. (2018) Metal Catalysts for Heterogeneous Catalysis: From Single Atoms to Nanoclusters and Nanoparticles. Chemical Reviews, 118, 4981-5079. https://doi.org/10.1021/acs.chemrev.7b00776

[3] Cole, K.J., Carley, A.F., Crudace, M.J., Clarke, M., Taylor, S.H. and Hutchings, G.J. (2010) Copper Manganese Oxide Catalysts Modified by Gold Deposition: The Influence on Activity for Ambient Temperature Carbon Monoxide Oxidation. Catalysis Letters, 138, 143-147. https://doi.org/10.1007/s10562-010-0392-2

[4] Harrison, P.G., Ball, I.K., Azelee, W., Daniell, W. and Goldfarb, D. (2000) Nature and Surface Redox Properties of Copper(II)-Promoted Cerium(IV) Oxide CO-Oxidation Catalysts. Chemistry of Materials, 12, 3715-3725. https://doi.org/10.1021/cm001113k

[5] Rynkowski, J.M. and Dobrosz-Gómez, I. (2009) Ceria-Zirconia Supported Gold Catalysts. In: Annales Universitatis Mariae Curie-Sklodowska, De Gruyter Poland, Vol. 64, 197-217.

[6] Yoshida, T., Murayama, T., Sakaguchi, N., Okumura, M., Ishida, T. and Haruta, M. (2018) Carbon Monoxide Oxidation by Polyoxometalate-Supported Gold Nanoparticulate Catalysts: Activity, Stability, and Temperature-Dependent Activation Properties. Angewandte Chemie International Edition, 57, 1523-1527. https://doi.org/10.1002/anie.201710424

[7] Kaneti, Y.V., Tanaka, S., Jikihara, Y., Nakayama, T., Bando, Y., Haruta, M., Hossain, M.S.A., Golberg, D. and Yamauchi, Y. (2018) Room Temperature Carbon Monoxide Oxidation Based on Two-Dimensional Gold-Loaded Mesoporous Iron Oxide Nanoflakes. Chemical Communications, 54, 8514-8517. https://doi.org/10.1039/C8CC03639I

[8] Brown, M., Green, A., Cohn, G. and Andersen, H. (1960) Purifying Hydrogen by Selective Oxidation of Carbon Monoxide. Industrial \& Engineering Chemistry, 52, 841-844. https://doi.org/10.1021/ie50610a025

[9] Oh, S.H. and Sinkevitch, R.M. (1993) Carbon Monoxide Removal from Hydrogen-Rich Fuel Cell Feedstreams by Selective Catalytic Oxidation. Journal of Catalysis, 142, 254-262. https://doi.org/10.1006/jcat.1993.1205

[10] Kahlich, M.J., Gasteiger, H.A. and Behm, R.J. (1997) Kinetics of the Selective CO Oxidation in $\mathrm{H} 2-\mathrm{Rich}$ Gas on $\mathrm{Pt} / \mathrm{Al}_{2} \mathrm{O}_{3}$. Journal of Catalysis, 171, 93-105. 
https://doi.org/10.1006/jcat.1997.1781

[11] Korotkikh, O. and Farrauto, R. (2000) Selective Catalytic Oxidation of CO in H2: Fuel Cell Applications. Catalysis Today, 62, 249-254.

https://doi.org/10.1016/S0920-5861(00)00426-0

[12] Manasilp, A. and Gulari, E. (2002) Selective CO Oxidation over Pt/alumina Catalysts for Fuel Cell Applications. Applied Catalysis B: Environmental, 37, 17-25. https://doi.org/10.1016/S0926-3373(01)00319-8

[13] Igarashi, H., Uchida, H., Suzuki, M., Sasaki, Y. and Watanabe, M. (1997) Removal of Carbon Monoxide from Hydrogen-Rich Fuels by Selective Oxidation over Platinum Catalyst Supported on Zeolite. Applied Catalysis A: General, 159, 159-169. https://doi.org/10.1016/S0926-860X(97)00075-6

[14] Watanabe, M., Uchida, H., Igarashi, H. and Suzuki, M. (1995) Pt Catalyst Supported on Zeolite for Selective Oxidation of CO in Reformed Gases. Chemistry Letters, 24, 21-22. https://doi.org/10.1246/cl.1995.21

[15] Igarashi, H., Uchida, H. and Watanabe, M. (2000) Mordenite-Supported Noble Metal Catalysts for Selective Oxidation of Carbon Monoxide in a Reformed Gas. Chemistry Letters, 29, 1262-1263.

https://doi.org/10.1246/cl.2000.1262

[16] Chagas, C.A., De Souza, E.F., De Carvalho, M.C.N.A., Martins, R.L. and Schmal, M. (2016) Cobalt Ferrite Nanoparticles for the Preferential Oxidation of CO. Applied Catalysis A: General, 519, 139-145. https://doi.org/10.1016/j.apcata.2016.03.024

[17] Liu, J., Liu, B., Fang, Y., Zhao, Z., Wei, Y., Gong, X.Q., Xu, C., Duan, A. and Jiang, G. (2014) Preparation, Characterization and Origin of Highly Active and Thermally Stable Pd-Ce $0.8 \mathrm{Zr}_{0.2} \mathrm{O}_{2}$ Catalysts via Sol-Evaporation Induced Self-Assembly Method. Environmental Science \& Technology, 48, 12403-12410. https://doi.org/10.1021/es5027008

[18] Lee, H.I. and White, J.M. (1980) Carbon Monoxide Oxidation over Ru (001). Journal of Catalysis, 63, 261-264. https://doi.org/10.1016/0021-9517(80)90078-0

[19] Goodman, D.W. and Peden, C.H.F. (1986) Carbon Monoxide Oxidation over Rhodium and Ruthenium: A Comparative Study. The Journal of Physical Chemistry, 90, 4839-4843. https://doi.org/10.1021/j100411a024

[20] Kim, Y.D., Over, H., Krabbes, G. and Ertl, G. (2000) Identification of $\mathrm{RuO}_{2}$ as the Active Phase in CO Oxidation on Oxygen-Rich Ruthenium Surfaces. Topics in Catalysis, 14, 95-100. https://doi.org/10.1023/A:1009063201555

[21] Over, H. and Muhler, M. (2003) Catalytic CO Oxidation over Ruthenium: Bridging the Pressure Gap. Progress in Surface Science, 72, 3-17. https://doi.org/10.1016/S0079-6816(03)00011-X

[22] Assmann, J., Narkhede, V., Breuer, N.A., Muhler, M., Seitsonen, A.P., Knapp, M., Crihan, D., Farkas, A., Mellau, G. and Over, H. (2008) Heterogeneous Oxidation Catalysis on Ruthenium: Bridging the Pressure and Materials Gaps and Beyond. Journal of Physics. Condensed Matter, 20, Article ID: 184017. https://doi.org/10.1088/0953-8984/20/18/184017

[23] Gao, F., McClure, S.M., Cai, Y., Gath, K.K., Wang, Y., Chen, M.S., Guo, Q.L. and Goodman, D.W. (2009) CO Oxidation Trends on Pt-Group Metals from Ultrahigh Vacuum to near Atmospheric Pressures: A Combined in Situ PM-IRAS and Reaction Kinetics Study. Surface Science, 603, 65-70.

https://doi.org/10.1016/j.susc.2008.10.031

[24] Cant, N.W., Hicks, P.C. and Lennon, B.S. (1978) Steady-State Oxidation of Carbon 
Monoxide over Supported Noble Metals with Particular Reference to Platinum. Journal of Catalysis, 54, 372-383. https://doi.org/10.1016/0021-9517(78)90085-4

[25] Kiss, J.T. and Gonzalez, R.D. (1984) Catalytic Oxidation of Carbon Monoxide over Rhodium/Silicon Dioxide. An in Situ Infrared and Kinetic Study. The Journal of Physical Chemistry, 88, 898-904. https://doi.org/10.1021/j150649a015

[26] Assmann, J., Narkhede, V., Khodeir, L., Löffler, E., Hinrichsen, O., Birkner, A., Over, H. and Muhler, M. (2004) On the Nature of the Active State of Supported Ruthenium Catalysts Used for the Oxidation of Carbon Monoxide: Steady-State and Transient Kinetics Combined with in Situ Infrared Spectroscopy. The Journal of Physical Chemistry B, 108, 14634-14642. https://doi.org/10.1021/jp0401675

[27] Assmann, J., Crihan, D., Knapp, M., Lundgren, E., Löffler, E., Muhler, M., Narkhede, V., Over, H., Schmid, M., Seitsonen, A.P. and Varga, P. (2005) Understanding the Structural Deactivation of Ruthenium Catalysts on an Atomic Scale under both Oxidizing and Reducing Conditions. Angewandte Chemie International Edition, 44, 917-920. https://doi.org/10.1002/anie.200461805

[28] Joo, S.H., Park, J.Y., Renzas, J.R., Butcher, D.R., Huang, W. and Somorjai, G.A. (2010) Size Effect of Ruthenium Nanoparticles in Catalytic Carbon Monoxide Oxidation. Nano Letters, 10, 2709-2713. https://doi.org/10.1021/nl101700j

[29] Soliman, N.K. (2019) Factors Affecting CO Oxidation Reaction over Nanosized Materials: A Review. Journal of Materials Research and Technology, 8, 2395-2407. https://doi.org/10.1016/j.jmrt.2018.12.012

[30] Ma, Q., Wang, D., Wu, M., Zhao, T., Yoneyama, Y. and Tsubaki, N. (2013) Effect of Catalytic Site Position: Nickel Nanocatalyst Selectively Loaded inside or outside Carbon Nanotubes for Methane Dry Reforming. Fuel, 108, 430-438. https://doi.org/10.1016/j.fuel.2012.12.028

[31] Zeng, S., Zhang, L., Jiang, N., Gao, M., Zhao, X., Yin, Y. and Su, H. (2015) Multi-Wall Carbon Nanotubes as Support of Copper-Cerium Composite for Preferential Oxidation of Carbon Monoxide. Journal of Power Sources, 293, 1016-1023.

https://doi.org/10.1016/j.jpowsour.2015.04.115

[32] Kozonoe, C.E., Brito, R.M. and Schmal, M. (2020) Influence of Feed Rate and Testing Variables for Low-Temperature Tri-Reforming of Methane on the Ni@MWCNT/Ce Catalyst. Fuel, 281, Article ID: 118749. https://doi.org/10.1016/j.fuel.2020.118749

[33] Zhao, X. and Ando, Y. (1998) Raman Spectra and X-Ray Diffraction Patterns of Carbon Nanotubes Prepared by Hydrogen Arc Discharge. Japanese Journal of Applied Physics, 37, 4846-4849. https://doi.org/10.1143/JJAP.37.4846

[34] Abdulrazzak, F.H., Alkiam, A.F. and Hussein, F.H. (2019) Behavior of X-Ray Analysis of Carbon Nanotubes. In: Saleh, H.E.D. and El-Sheikh, S.M.M., Eds., Chapter 7 Perspective of Carbon Nanotubes, BoD-Books on Demand, 109-124.

[35] Bond, G.C. (1987) Heterogeneous Catalysis: Principles and Applications (Oxford Chemistry). 2nd Edition, Oxford University Press, New York.

[36] Rojas, J.V., Toro-Gonzalez, M., Molina-Higgins, M.C. and Castano, C.E. (2016) Facile Radiolytic Synthesis of Ruthenium Nanoparticles on Graphene Oxide and Carbon Nanotubes. Materials Science \& Engineering B: Solid-State Materials for Advanced Technology, 205, 28-35. https://doi.org/10.1016/j.mseb.2015.12.005

[37] Saleh, T.A. (2011) The Influence of Treatment Temperature on the Acidity of MWCNT Oxidized by $\mathrm{HNO}_{3}$ or a Mixture of $\mathrm{HNO}_{3} / \mathrm{H}_{2} \mathrm{SO}_{4}$. Applied Surface Science, 257, 7746-7751. https://doi.org/10.1016/j.apsusc.2011.04.020

[38] Santos, A.R., Menezes, D.B., Ellena, J. and Andrade, M.B. (2019) Aplicação da es- 
pectroscopia Raman na caracterização de minerais pertencentes a uma geocoleção. Química Nova, 42, 489-496.

[39] Zdrojek, M., Gebicki, W., Jastrzebski, C., Melin, T. and Huczko, A. (2004) Studies of Multiwall Carbon Nanotubes Using Raman Spectroscopy and Atomic Force Microscopy. In: Solid State Phenomena, Trans Tech Publications Ltd., Stafa-Zurich, 265-268. https://doi.org/10.4028/www.scientific.net/SSP.99-100.265

[40] Foldvari, M., et al. (2012) Pharmaceutical Characterization of Solid and Dispersed Carbon Nanotubes as Nanoexcipients. International Journal of Nanomedicine, 2012, 403-415. https://doi.org/10.2147/IJN.S27442

[41] Shih, Y.T., Lee, K.Y. and Huang, Y.S. (2014) Electrochemical Capacitance Characteristics of Patterned Ruthenium Dioxide-Carbon Nanotube Nanocomposites Grown onto Graphene. Applied Surface Science, 294, 29-35.

https://doi.org/10.1016/j.apsusc.2013.12.145

[42] Schmal, M. (2016) Heterogeneous Catalysis and Its Industrial Applications. Springer, Berlin. https://doi.org/10.1007/978-3-319-09250-8 1

[43] Ananth, A., Jeong, R.H. and Boo, J.-H. (2020) Preparation, Characterization and CO Oxidation Performance of $\mathrm{Ag}_{2} \mathrm{O} / \gamma-\mathrm{Al}_{2} \mathrm{O}_{3}$ and $\left(\mathrm{Ag}_{2} \mathrm{O}+\mathrm{RuO}_{2}\right) / \gamma-\mathrm{Al}_{2} \mathrm{O}_{3}$ Catalysts. Surfaces, 3, 251-264. https://doi.org/10.3390/surfaces3020019

[44] Her, J.H., Kennon, B.S., Shum, W.W., Stephens, P.W. and Miller, J.S. (2008) Structure and Magnetic Properties of $\mathrm{Ln}^{\mathrm{III}}\left[\mathrm{Ru}_{2}\left(\mathrm{CO}_{3}\right)_{4}\right] \cdot 8 \mathrm{H}_{2} \mathrm{O}$. Inorganica Chimica Acta, 361, 3462-3464. https://doi.org/10.1016/j.ica.2008.02.043

[45] Park, J.N., Kuk Shon, J., Jin, M., Sung Kong, S., Moon, K., Ok Park, G., Boo, J.H. and Man Kim, J. (2011) Room-Temperature CO Oxidation over a Highly Ordered Mesoporous $\mathrm{RuO}_{2}$ Catalyst. Reaction Kinetics, Mechanisms and Catalysis, 103, 87-99. https://doi.org/10.1007/s11144-011-0284-5

[46] Reddy, B.M., Rao, K.N. and Bharali, P. (2009) Copper Promoted Cobalt and Nickel Catalysts Supported on Ceria-Alumina Mixed Oxide: Structural Characterization and CO Oxidation Activity. Industrial \& Engineering Chemistry Research, 48, 8478-8486. https://doi.org/10.1021/ie900755b 